\title{
Peran Guru Pendidikan Agama Kristen Dalam Perkembangan Moral Siswa Kelas 5 Di Sekolah Dasar Inpres Pante Deere Kabupaten Alor
}

\author{
Esterie Rempe', Tri Supartini
}

\begin{abstract}
Abstrak
Tujuan penulisan skripsi ini adalah untuk mengetahui bagaimana peran guru Pendidikan Agama Kristen dalam perkembangan moral siswa kelas 5 di Sekolah Dasar Inpres Pante Deere Kabupaten Alor. Guru PAK adalah suatu profesi yang dilakukan oleh seseorang Kristen yang cakap mengajar tentang iman Kristen sehingga anak didik dapat memperoleh pertumbuhan secara rohani. Peran guru PAK antara lain sebagai pendidik, pembimbing dan motivator. Perkembangan moral anak ada tiga tingkatan. Tingkatan pertama prakonvensional, tingkatan kedua konvensional dan tingkatan ketiga pascakonvensional. Penulis menggunakan jenis penelitian dengan menggunakan angket, dan wawancara. Dari penelitian yang telah dilakukan, maka diperoleh kesimpulan bahwa: pertama, dari ketiga peran guru yaitu sebagai pendidik, pembimbing dan sebagai motivator sudah sangat baik. Guru telah menjalankan perannya dengan sangat baik. Guru mendidik anak didiknya untuk memiliki perilaku jujur, sopan dan menghormati orang tua. Guru juga mendidik dengan mangajarkan materi pelajaran dengan baik dan menanamkan nilai-nilai kebenaran firman Tuhan. Guru membimbing anak didik dengan baik seperti membimbing anak ketika menghadapi masalah pelajaran maupun dengan orang-orang di sekitar dan guru juga memberi motivasi kepada anak didik dengan sangat baik dapat dilihat ketika guru memberikan pujian kepada anak saat anak mendapatkan nilai yang baik dan memberikan semangat siswa dalam mengikuti pelajaran di sekolah. Kedua, perkembangan moral anak rata-rata berada pada tingkat prakonvensional tahap kedua orentasi intrumental-relativis karena bergantung pada faktor pribadi dan kesenangan dari anak itu sendiri, seperti suka berkata-kata kotor, memukul teman dan berkata kasar merupakan bentuk kesenangan dari anak itu sendiri, yang menjadi faktor penyebabnya ialah lingkungan tempat tinggal anak didik yang membuat anak mengikuti perilaku tersebut. Ketiga, peran guru pendidikan agama kristen dalam perkembangan moral siswa kelas 5 dikatakan kurang berpengaruh karena berdasarkan hasil angket, pengamatan dan wawancara dapat dijumpai bahwa walaupun guru sudah menjalankan peran sebagai, pendidik, pembimbing, dan sebagai motivator dengan sangat baik, namun anak-anak sendiri memilih untuk tidak mengikuti ajaran atau pendidikan yang diberikan oleh guru.
\end{abstract}

Kata kunci : Moral, Peran, Guru, Siswa, Pendidikan Agama Kristen 


\section{Pendahuluan}

\section{Latar Belakang Masalah}

Setiap individu pasti mengalami perkembangan pada semua aspek dalam dirinya secara terus-menerus dan tidak pernah berhenti. Untuk memahami perkembangan tersebut, salah satunya perlu ditinjau dari perkembangan moral. Moral merupakan adat istiadat, kebiasaan, peraturan atau nilai-nilai atau tata cara kehidupan.

Individu dalam kehidupannya pasti mengalami perkembangan moral, di mana perkembangan moral ini di mulai pada usia anak. Dalam perkembangan hidupnya seorang anak akan diperhadapkan dengan norma-norma yang berlaku di dalam masyarakat. Normanorma inilah yang biasanya berkaitan dengan moral, di mana perilaku seseorang dalam kehidupan baik buruknya sikap seseorang dinilai berdasarkan norma-norma yang berlaku dalam masyarakat.

Menurut Kamus Besar Bahasa Indonesia moral adalah (ajaran) baik buruk yang diterima umum mengenai perbuatan, sikap, kewajiban, dan sebagainya; akhlak, budi pekerti, susila. ${ }^{1}$ Istilah moral berasal dari kata Latin yaitu Mos (Moris) yang berarti adat istiadat, kebiasaan, tata cara kehidupan. Moralitas berhubungan dengan keadaan nilai moral yang berlaku dalam suatu kelompok sosial atau masyarakat. ${ }^{2}$ Dapat dikatakan bahwa moral adalah nilai-nilai atau tata cara kehidupan yang berlaku di masyarakat. Dalam buku dasar teori perkembangan anak mengatakan bahwa seseorang dikatakan telah memperkembangkan aspek moral, bilamana ia telah menginternalisasikan atau telah mempelajari aturan-aturan atau kaidah kehidupan di dalam masyarakat dan bisa memperlihatkan dalam perilaku yang terus menerus atau menetap. ${ }^{3}$ Oleh karena itu, moral dikatakan berkembang bilamana seseorang mempelajari aturan-aturan yang ada di masyarakat dan melakukannya secara terus menerus dan menetap. Perkembangan moral seorang anak sejalan dengan perkembangan kognitif seorang anak jadi semakin bertambahnya nilai kognitif anak, maka makin banyak pula nilai-nilai moral yang ditangkap dan dimengerti oleh anak. ${ }^{4}$ Hakikat moralitas adalah kecenderungan menerima dan menaati sistem peraturan. ${ }^{5}$

Pada anak usia 10 tahun, anak sudah dapat mengetahui dengan baik alasan-alasan atau prinsip-prinsip yang mendasari suatu aturan. Pada usia ini anak sudah dapat mengetahui dan membedakan yang baik dan buruk. Anak sudah mengetahui konsep-konsep moral seperti kejujuran, hak milik, keadilan dan kehormatan. Dan melakukan perbuatan yang baik yang dianggap baik oleh orang lain. ${ }^{6}$

${ }^{1}$ Kamus Besar Bahasa Indonesia, s.v. "Moral".

${ }^{2}$ Singgih D. Gunarsa dan Yulia Singgih D. Gunarsa, Psikologi Perkembangan Anak Dan Remaja (Jakarta: BPK Gunung Mulia, 1991), 61.

${ }^{3}$ Singgih D. Gunarsa, Dasar Dan Teori Perkembangan Anak (Jakarta: BPK Gunung Mulia, 1982), 196.

${ }^{4}$ Singgih D. Gunarsa dan Yulia Singgih D. Gunarsa, Psikologi Perkembangan Anak Dan Remaja (Jakarta: BPK Gunung Mulia, 1991), 66.

${ }^{5}$ Laila Maharani, "Perkembangan Moral pada Anak," Jurnal Bimbingan dan Konseling 1, No. 2 (2014):104.

${ }^{6}$ Singgih D. Gunarsa dan Yulia Singgih D. Gunarsa, Psikologi Perkembangan Anak Dan Remaja (Jakarta: BPK Gunung Mulia, 1991), 69. 
Maka dari itu pada masa ini, pengertian anak tentang baik buruk, tentang normanorma atau aturan serta nilai-nilai yang berlaku di lingkungan menjadi bertambah dan juga lebih mudah, tidak sekaku saat di usia kanak-kanak awal. Mereka mulai memahami bahwa penilaian baik buruk atau aturan-aturan yang berlaku di masyarakat.

Perkembangan nilai moral dipengaruhi oleh keluarga, guru dan juga lingkungan sekitar anak. ${ }^{7}$ Salah satu yang mempengaruhi perkembangan moral anak adalah peran guru.

Guru memiliki peran penting dalam mengembangkan anak usia sekolah dasar. Sebagai orang yang berprofesi dalam bidang pendidikan, guru bertanggung jawab dalam membentuk siswa untuk mencapai kedewasaannya masing-masing. Dalam UU Guru dan Dosen No. 14 Tahun 2005 (BAB 1, Pasal 1, ayat 1), menegaskan bahwa "Guru adalah pendidik profesional dengan tugas utama mendidik, mengajar, membimbing, mengarahkan, melatih, dan mengevaluasi peserta didik pada pendidikan anak usia dini jalur pendidikan formal, pendidikan dasar, dan pendidikan menengah". ${ }^{8}$ Dapat dikatakan guru membantu dan mengupayakan perkembangan anak murid dalam mengoptimalkan segala potensi yang ia milik. Peran guru dalam proses belajar mengajar ialah sebagai pengajar, pemimpin kelas, pembimbing, pengatur lingkungan, partisipan, ekspeditor, perencana, suvervisor, motivator dan konselor. ${ }^{9}$ Peranan guru dalam meningkatkan prestasi belajar peserta didik yaitu guru memiliki peran yang sangat penting dalam menentukan kuantitas dan kualitas pengajaran yang dilaksanakannya. ${ }^{10}$

Guru memiliki unsur penting dalam kegiatan mengajar. Gurulah yang membimbing peserta didiknya untuk belajar mengenal, memahami, dan menghadapi dunia dimana tempat ia berada. ${ }^{11}$ Dengan kata lain guru merupakan faktor terpenting yang bukan hanya dalam menyukseskan kegiatan belajar mengajar melainkan dalam bentuk moral dan bukan hanya memberikan pemahaman secara kognitif saja tetapi mendidik dalam nilai-nilai moral. Di samping perilaku moral ada juga yang dikatakan perilaku tak bermoral yang disebut dengan perilaku yang melanggar standar sosial atau nilai-nilai yang berlaku di masyarakat. ${ }^{12}$

Masalah moralitas di kalangan siswa saat ini merupakan salah satu masalah yang harus mendapat perhatian dari semua pihak. Berbagai perubahan yang terjadi dalam seluruh aspek kehidupan siswa di mulai dari pergaulan, gaya hidup dan cara pandang sangat mempengaruhi perilaku dasar siswa. Ini akan menjadi kekhawatiran bagi para orang tua murid sebab mereka dengan pasti menginginkan putra-putri mereka kelak menjadi orang yang sukses dan berguna.

Dalam proses belajar mengajar banyak ditemukan fakta pendidikan hanya mentransfer ilmu dan pedoman pada pencapaian target mata pelajaran yang dikuasai siswa tanpa memperlihatkan perilaku mereka. Sehingga tidak salah apabila pendidikan di sekolah

${ }^{7}$ Singgih D. Gunarsa, Psikologi Perkembangan (Jakarta: BPK Gunung Mulia, 1972), 40-43.

${ }^{8}$ B. S. Sidjabat, Mengajar Secara Profesional (Bandung: Kalam Hidup, 2011), 99.

${ }^{9}$ Moh. Uzer Usman, Menjadi Guru Profesional (Bandung: Remaja Rosdakarya, 1998), 9.

${ }^{10}$ Cahyono, "Pengaruh Kedisiplinan Terhadap Peningkatan Prestasi Belajar Peserta Didik Pada Mata Pelajaran PKN Di SMK Pasundan 1 Subang," Jurnal PGSD Sekolah Tinggi Keguruan dan Ilmu Pendidikan Subang I, No. 2 (Juli 2016):173, diakses 27 Februari 2018, jurnalistkipsubang.ac.id/index.php/jurnal/article/view/25.

${ }^{11}$ John M. Nainggolan, Guru Agama Kristen: Sebagai Panggilan dan profesi (Bandung: Bina Media Informasi:2010), 22.

${ }^{12}$ Laila Maharani, "Perkembangan Moral pada Anak,.” Jurnal Bimbingan dan Konseling 1, No. 2 (2014):105. 
hanya dijadikan panggung untuk mendapatkan rangking. ${ }^{13}$ Oleh sebab itu pendidikan agama sangat penting karena salah satu upaya membentuk kualitas internal sebagai pendorong manusia berperilaku moral. Perilaku moral yang sesungguhnya tidak saja sesuai dengan aturan atau norma masyarakat tetapi juga harus dilakukan dengan diatur, diawali, dan dikendalikan dari dalam diri yang diiringi perasaan dan tanggung jawab pribadi. ${ }^{14}$ Pendidikan agama sangatlah penting bagi pendidikan seorang anak, agar anak tersebut memiliki moral yang sesuai dengan kebenaran-kebenaran firman Tuhan. Tujuan pendidikan Kristen secara khusus adalah usaha untuk membentuk dan membimbing peserta didik untuk berkembang mencapai kepribadian utuh yang mencerminkan sebagai gambar dan rupa Allah yang memiliki sifat kasih dan ketaat pada TUHAN, memiliki kecerdasan, keterampilan, berbudi pekerti, kesabaran dan memelihara lingkungan hidup, serta ikut bertanggung jawab dalam pembangunan masyarakat, berbangsa dan bernegara.

\section{Pokok Masalah}

Dalam penulisan skripsi ini yang menjadi pokok masalah adalah:

Bagaimana peran guru Pendidikan Agama Kristen dalam perkembangan moral siswa kelas 5 di SD Inpres Pante Deere Kabupaten Alor?

\section{Tujuan Penelitian}

Berdasarkan masalah diatas, maka dalam penulisan skripsi ini ada beberapa tujuan yang penulis ingin capai:

Untuk mengetahui peran guru Pendidikan Agama Kristen dalam perkembangan moral siswa kelas 5 di SD Inpres Pante Deere Kabupaten Alor.

\section{Manfaat Penelitian}

Dalam penulisan skripsi ada beberapa manfaat yang diharapkan oleh penulis dalam penulisan proposal ini:

Pertama, menjadi konstribusi bagi guru Pendidikan Agama Kristen berperan dalam perkembangan moral siswa.

Kedua, sebagai bahan evaluasi bagi SD Inpres Pante Deere.

Ketiga, sebagai penambahan pengetahuan bagi penulis sebagai calon guru PAK.

Keempat, sebagai salah satu persyaratan dalam menyelesaikan pendidikan strata satu di Sekolah Tinggi Theologia Jaffray Makassar.

\section{Metode Penelitian}

Dalam penulisan skripsi ini, metode penulisan yang digunakan oleh penulis adalah:

Pertama, menggunakan buku-buku, jurnal dan juga artikel dari internet sebagai bahan atau referensi untuk membantu penulis dalam penyelenggaraan penulisan skripsi.

Kedua, memberikan angket kepada siswa kelas 5 di Sekolah Dasar Inpres Pante Deere dan wawancara yang berkaitan dengan masalah-masalah yang relevan dengan objek

13 “Bukan Sekedar Teranfer Pengetahuan, Sekolah Juga Sebagai Pendidikan Karakter,” diakses 18 Februari 2018, htpp://sentananews.com/news/suara-kita/bukan-sekedar-tranfer-pengetahuan-sekolah-juga-se17656

${ }^{14}$ Fatimah Ibda, "Pendidikan Moral Anak Melalui Pengajaran Bidang Studi PPKN Dan pendidikan Agama," Jurnal Ilmiah Didaktika XII, No. 2(Februari 2013):343, diakses 18 Februari 2018, https://jurnal.arrainary.ac.id/index.php/didaktika/article/viewFile/457/368. 
penelitian untuk mendapatkan data yang lengkap serta melakukan wawancara kepada guru Pendidikan Agama Kristen dan siswa.

\section{Batasan penelitian}

Pokok pembahasan yang akan dibahas dalam karya ilmiah ini adalah: Peran guru Pendidikan Agama Kristen dalam perkembangan moral siswa kelas 5 di Sekolah Dasar Inpres Pante Deere Kabupaten Alor.

\section{Kesimpulan}

Pertama, dari ketiga peran guru yaitu sebagai pendidik, pembimbing dan sebagai motivator sudah sangat baik. Guru telah menjalankan perannya dengan sangat baik. Guru mendidik anak didiknya untuk memiliki perilaku jujur, sopan dan menghormati orang tua. Guru juga mendidik dengan mangajarkan materi pelajaran dengan baik dan menanamkan nilai-nilai kebenaran firman Tuhan. Guru membimbing anak didik dengan baik seperti membimbing anak ketika menghadapi masalah pelajaran maupun dengan orang-orang di sekitar dan guru juga memberi motivasi kepada anak didik dengan sangat baik dapat dilihat ketika guru memberikan pujian kepada anak saat anak mendapatkan nilai yang baik dan memberikan semangat siswa dalam mengikuti pelajaran di sekolah.

Kedua, perkembangan moral anak di mana perilaku moral anak berada pada tingkat prakonvensional tahap kedua orentasi intrumental-relativis karena bergantung pada faktor pribadi dan kesenangan dari anak itu sendiri, seperti suka berkata-kata kotor, memukul teman dan berkata kasar merupakan bentuk kesenangan dari anak itu sendiri, yang menjadi faktor penyebabnya ialah lingkungan tempat tinggal anak didik yang membuat anak mengikuti perilaku tersebut.

Ketiga, peran guru pendidikan agama kristen dalam perkembangan moral siswa kelas 5 dikatakan kurang berpengaruh karena berdasarkan hasil angket, pengamatan dan wawancara dapat dijumpai bahwa walaupun guru sudah menjalankan peran sebagai, pendidik, pembimbing, dan sebagai motivator dengan sangat baik, namun anak-anak sendiri memilih untuk tidak mengikuti ajaran atau pendidikan yang diberikan oleh guru.

\section{Kepustakaan}

Astika, Made, DAN Bunga, Selvianty. "Hubungan Kompetensi Sosial Guru Kristen Terhadap Perkembangan Karakter Siswa: Tantangan Pendidikan Kristen Dalam Mencerdaskan Youth Generation" Jurnal Jaffray [Online], Volume 14 Nomor 1 (10 Maret 2016).

Black, James A. dan Dean J. Champion. Metode dan Masalah Penelitian Sosial. Bandung: Refika Aditama, 1999.

Brake, Andrew. Spiritual Formation. Bandung: Yayasan Kalam Hidup, 2014.

Boiliu, Noh Ibrahim. "Misi Pendidikan Agama Kristen dan Problem Moralitas Anak." Jurnal Pendidikan Agama Kristen Regula Fidel 1 No.1 (Maret 2016):1-26.

Busthan, Paskalinus C. Materi Kuliah: Seminar Pendidikan Agama Kristen. Makassar: Sekolah Tinggi Theologia Jaffray, 2018. 
Cahyono. "Pengaruh Kedisiplinan Terhadap Peningkatan Prestasi Belajar Peserta Didik Pada Mata Pelajaran PKN Di SMK Pasundan 1 Subang.” Jurnal PGSD Sekolah Tinggi Keguruan dan Ilmu Pendidikan Subang I, No. 2 (Juli 2016):1-12.

Gunarsa, Singgih D. dan Yulia Singgih D. Gunarsa, Psikologi Perkembangan Anak Dan Remaja (Jakarta: BPK Gunung Mulia, 1991.

Gunarsa, Singgih D. Dasar Dan Teori Perkembangan Anak. Jakarta: BPK Gunung Mulia, 1982. . Psikologi Perkembangan. Jakarta: BPK Gunung Mulia, 1972.

Gunarsa, Y. Singgih D. dan Singgih D. Gunarsa. Psikologi untuk Membimbing. Jakarta: BPK Gunung Mulia, 1980.

Hadiwijono, Harun. Inilah Sahadatku. Jakarta: BPK Gunung Mulia, 1981.

H, Zaenuddin M. The Best Teachers:200 Dalil Motivasi untuk Menjadi Guru Terbaik \& Sukses. Jakarta: indeks, 2017.

Homrighausen, E. G. dan Enklaar. Pendidikan Agama Kristen. Jakarta: BPK Gunung Mulia, 1957.

Ibda, Fatimah. "Pendidikan Moral Anak Melalui Pengajaran Bidang Studi PPKN Dan pendidikan Agama.” Jurnal Ilmiah Didaktika XII, No. 2 (Februari 2013):1-10. Diakses 18 Februari 2018. https://jurnal.arrainary.ac.id/index.php/didaktika/article/viewFile/457/368.

Ibung, Dian. Mengembangkan Nilai Moral pada Anak. Jakarta: Elex Media Komputindo, 2009.

Ismail, Andar. Ajarlah Mereka Melakukan. Jakarta: BPK Gunung Mulia, 1998.

Kurniawan, Syamsul. Pendidikan Karakter: Konsepsi \& Implementasinya secara Terpadi Di Lingkungan Keluarga, Sekolah, Perguruan Tinggi, dan Masyarakat. Yogyakarta: Ar-Ruzz Media, 2013.

Kusmitasari, Reni Muh. Najib Husain, Husain. "Persepsi Mahasiswa Pada Sistem Layanan Sirkulasi di UPT Perpustakaan Universitar Halu Oleo.” Jurnal Ilmu Komunikasi UHO Vol 1, No. 3 (2016):1-22. Diakses 18 Juni 2018. http://ojs.uho.ac.id/index.php/KOMUNIKASI/search/authors/view?firstName=Reni\& $\underline{\text { middleName }=\& \text { lastName }=\text { Kusmitasari\&a99ffiliation }=\text { Halu } \% 200 \text { University \& country }}$ 三.

Maharani, Laila. "Perkembangan Moral Pada Anak.” Jurnal Bimbingan Dan Konseling 1, No. 2 (2014):1-6.

Mudlfir, Ali. Pendidik Profesional. Jakarta: RajaGrafindo Persada, 2012.

Nainggolan, John M. Guru Agama Kristen: Sebagai Panggilan dan profesi. Bandung: Bina Media Informasi, 2010.

Nasir, Moh. Metode Penelitian. Jakarta: Ghalia Indonesia, 1988.

P, Harianto G. Pendidikan Agama Kristen dalam Alkitab dan Dunia Pendidikan Masa Kini. Yogyakarta: ANDI, 2012.

Putranto, Mudji Sutrisno dan Hendar. Teori-Teori Kebudayaan. Yogyakarta: KANISIUS, 2005.

Richards, Lawrence O. Pelayanan Kepada Anak-anak. Bandung: Kalam Hidup, 2007.

Saifuddin. Pengelolaan Pembelajaran Teoritis dan Praktis. Yogyakarta: Deapublish, 2014. Setiawani, Mary Go. Pembaruan Mengajar. Bandung: Yayasan Kalam Hidup, 1993. 
Sidjabat, B. S. Mengajar Secara Profesional. Bandung: Yayasan Kalam Hidup, 2011. Mengajar Secara Profesional. Bandung: Yayasan Kalam Hidup, 2000. . Menjadi Guru Profesional. Bandung: Yayasan Kalam Hidup, 2009.

Sidjabat, Samuel. Strategi Pendidikan Kristen: Suatu Tinjauan Teologi-Filosofis. Yogyakarta: Yayasan ANDI, 1994.

Sit, Masganti. Psikologi Perkembangan Anak Usia Dini. Jakarta: Kharisma Putra Utama, 2017.

Siyoto, Sandu. Dasar Metodologi Penelitian. Karanganyar:Literasi Media Publishing, 2015.

Subagyo, Andreas B. Pengantar Riset Kualitatif dan Kuantitatif. Bandung: Yayasan Kalam Hidup, 2004.

Sugiarti, dan Eggy Fajar Andalas, Perspektif Etik Dalam Penelitian Sastra. Malang: UMM Press, 2018.

Sugiyono. Metode Penelitian Kuantitatif, Kualitatif dan R\&D. Bandung: ALFABETA, 2015.

Susanto, Ahmad. Perkembangan Anak Usia Dini: Pengantar dalam Berbagai Aspeknya. Jakarta: Kencana, 2011.

Uno, Hamzah B. Tugas Guru Dalam Pembelajaran Aspek Yang Memengaruhi. Jakarta: Pt Bumi Aksara, 2016.

Usman, Husaini dan Purnomo Setiady Akbar. Metode Penelitian Sosial. Jakarta: Bumi Aksara, 1996.

Usman, Moh. Uzer. Menjadi Guru Profesional. Bandung: Remaja Rosdakarya, 1998.

Wijaya, Hengki (ed.). Metodologi Penelitian Pendidikan Teologi. Makassar: Sekolah Tinggi Theologia Jaffray, 2016.

Z, Mulyana A. Rahasia Menjadi Guru Hebat. Surabaya: Grasindo, 2010. 